\title{
A defesa hobbesiana do autoritarismo
}

Mauricio Fontana Filho ${ }^{1}$

\section{Introdução}

Os imigrantes ilegais são, de modo geral, compostos de assassinos, ladrões, estupradores e terroristas? Tal foi a afirmação feita por um líder de Estado democraticamente eleito. $\mathrm{O}$ que se investiga na presente pesquisa são os alicerces de políticas repressivas, arbitrárias e exclusivas. O que dá vida às chamadas políticas do medo? O que motiva a ser o legislar preventivo?

O método de pesquisa é o hipotético-dedutivo. Pensadores conservadores foram analisados em ordem de explorar as suas teorias de Estado e, com isso, compreender os seus pontos de partida. Outros, de raciocínio mais liberal, foram utilizados apenas em complemento e com fins de problematização. Os pensadores escolhidos para modelar a escrita o foram em função de sua relevância, acessibilidade e atualidade. Por isso fazemos uso, ao longo do texto, de autores clássicos para o desenvolvimento lógico.

O medo é uma força competente em fazer-se dominar e legitimar políticas violentas exclusivas por instilar incerteza no coração dos povos, garantindo assim o apoio a atitudes extremas que, em tempos de normalidade, jamais seriam mesmo consideradas. Investigamos o raciocínio que as apoia.

É quando um líder de Estado se apoia na demonização de imigrantes para governar que o artigo científico se justifica por si mesmo. Escrevemos para colorir as motivações de tais governantes de modo que governados melhor as enxerguem.

\section{A premissa hobbesiana}

Na obra Leviatã ou a matéria, forma e poder de um estado eclesiástico e civil de Thomas Hobbes (2014), o homem é tomado como um ser vil e sedento por

\footnotetext{
${ }^{1}$ Bacharel em Direito pela Universidade Regional do Noroeste do Estado do Rio Grande do Sul, UNIJUI. Email: mauricio442008@ hotmail.com.
} 
poder, sendo o estado de natureza considerado um estado de guerra de todos os homens contra todos os homens. A partir deste pressuposto, um modelo de Estado, a monarquia absoluta, com poderes ilimitados, indivisíveis e imprescritíveis é erigida com o objetivo de estagnar os males advindos da natureza humana. A expressão premissa hobbesiana significa um ponto de partida pessimista quanto ao conceito de homem que legitima ações arbitrárias, despóticas e invasivas por parte do Estado.

O fundamento do pensamento de autores intrinsecamente autoritários como Félix Sardá y Salvany (1949), Carl Schmitt (2009), Edmund Burke (2016), José Ortega y Gasset (2016), Arthur Schopenhauer (2018), Roger Scruton (2015) e Hobbes (2014) se assenta em pressupostos pessimistas, a partir dos quais discursos também pessimistas são erigidos em busca de instituições fortes e restritivas providas da capacidade de apequenar a margem de ação individual.

"Todas as teorias do Estado e ideias políticas poderiam ser examinadas quanto a sua antropologia e classificadas segundo o critério se pressupõem ou não, consciente ou inconscientemente, um ser humano "mau por natureza" ou um "bom por natureza"." (SCHMITT, 2009, p. 63). A maldade pode se manifestar como corrupção, debilidade, covardia, tolice ou mesmo como brutalidade, impulsividade, vitalidade ou irracionalidade; enquanto que a bondade, com as variações correspondentes, como racionalidade, perfectibilidade, dirigibilidade, educabilidade e pacificidade (SCHMITT, 2009).

A premissa hobbesiana é a favorita de pensadores conservadores. Ela indica que os homens são violentos, como aponta Schopenhauer (2018), ou ignorantes, como aponta Ortega y Gasset (2016), logo precisam ter seus ânimos contidos pelo peso da espada. Na medida em que o homem for considerado mais propenso à bondade, menor será a necessidade de coerção institucional na sociedade, enquanto que se os povos forem considerados mais propensos à maldade, maior será essa necessidade (SCHMITT, 2009).

"O pessimismo é a tendência de concentrar-se no negativo, de esperar o pior ou de fazer as interpretações mais sombrias possíveis.” (MISCHEL, 2016, p.101). Pontos de partida pessimistas são as raízes que tendem a legitimar a repressão institucional preventiva, seja essa repressão subjetiva pela Igreja ou objetiva pelo Estado. Quando os povos são tomados como bárbaros ou inferiores, 
ignorantes ou incapazes, justificativas para privá-los de suas liberdades são suscitadas (SCHMITT, 2009).

O que dá ânimo aos discursos favoráveis à censura e ações militares preventivas, restrição de liberdades sexuais, de associação e reunião, oposição ao sufrágio, liberdade de pensamento e crença, são as desconfianças acerca do que o homem fará quando em usufruto das supracitadas liberdades, as quais são tomadas, por muitos, como um abstrato repleto de venenos e incertezas. Ao crer com veemência na pior das hipóteses, se desenvolvem estruturas institucionais para endereçar esses medos. Em outras palavras, ao atribuirmos vício ao homem, atribuímos também meios coercitivos de endereçá-lo (FONTANA FILHO, 2019).

A Igreja molda o conceito pecaminoso de homem de Sardá y Salvany (1949); o Estado Absoluto de Hobbes (2014) estagna seus intentos malignos; a Aristocracia Cultural de Ortega y Gasset (2016) impede que as massas negligenciem o poder. A premissa faz a teoria de Estado. "A falácia da melhor das hipóteses surge quando a esperança prevalece sobre a razão, na presença de uma escolha importante" afirma Scruton (2015, p.60). A premissa hobbesiana, por outro lado, escapa da falácia, isso porque pressupõe não a melhor das hipóteses, mas a pior de todas elas.

O MEDO É A MAIS PODEROSA das emoções humanas. [...] onde há medo surge a política do medo. A saber, a utilização deliberada do óbvio desejo que as pessoas têm de proteção para estabelecer um estado de emergência permanente que corrói e por fim nega na prática as liberdades civis e as instituições democráticas. [...] em muitos países entramos em um mundo no qual as crianças crescem no medo. E no qual os cidadãos aceitam que os vigiem e os controlem eletronicamente, que os revistem em suas viagens, que os detenham preventivamente, que militarizem o espaço público. Porque essas precauções são sempre em relação "aos outros", àqueles cuja etnia ou religião os torna suspeitos de ser suspeitos. [...] o que constitui exceção por motivos de segurança vai se transformando na regra que rege nossas vidas. (CASTELLS, 2017, p. 29).

Quando, em 2019, o presidente norte-americano Donald J. Trump disse que os imigrantes ilegais que estavam tentando entrar pelo México eram em sua maioria ladrões, estupradores, assassinos e terroristas, ele, inerentemente ao seu discurso refletiu um pedido por maior invasão do Estado e subtração de liberdades das pessoas que buscavam asilo em seu país. Trata-se de política do medo. Ele 
apontou um vício que, se deixado desamparado, um mal sem igual seria outorgado ao povo estadunidense (FONTANA FILHO; PERSICH; TONEL, 2019). O ódio nazista direcionado por Adolf Hitler (2018) aos judeus, tomados como maus e culpados pela perda da Primeira Grande Guerra por parte da Alemanha, seguiu a mesma lógica que por fim garantiria um Estado de exceção contínuo e irrecorrível (Jacobson, 2018).

O senador norte-americano Ron Paul (2013) aponta que George W. Bush, quando da ocorrência do atentado de 11 de setembro de 2001, com o fim de legitimar ações mais incisivas em direção à guerra ao terror fez uso de um discurso tendencioso a unificar o povo iraquiano como sendo integralmente mau. Aos que discordavam de si, bem, não seriam verdadeiros patriotas. Os seus discursos inflamatórios levariam à aprovação pelo congresso do Patriot Act, a legislação que materializou o Estado de exceção. Antes disso, "os vietnamitas eram chamados de 'amarelos', como se fossem sub-humanos e assim não merecessem simpatia." (MILGRAM, 1983, p. 199). Fato ocorrido durante a Guerra do Vietnã. Eles eram demonizados, como o foram os soviéticos em razão de suas políticas antitéticas às norte-americanas, o que garantia maior margem por parte do Estado estadunidense para impor políticas de repressão em massa (MILGRAM, 1983).

Em ordem de interagir com um padrão nocivo de homens, requer-se uma abundância mais significativa de regras que limitem as condutas humanas. Philip Zimbardo (2015, p.302) afirma que "as regras são modos formais e simplificados de controlar comportamentos complexos e informais. Elas funcionam externalizando os regulamentos, estabelecendo o que é necessário, aceitável e recompensado, e o que é inaceitável, e, portanto, punível." Muitas vezes, as regras têm vida própria e arbitrária, sendo a força da autoridade legal até mesmo quando não são mais relevantes. Algumas regras são essenciais para a efetiva coordenação do comportamento social, porém, outras são meras projeções da dominação daqueles que as criam.

Quanto maior é a liberdade concedida ao homem, maior será o impacto da sua natureza sobre o seu meio, seja o homem bom ou mau. Assim, a liberdade e o crime se encontram indissoluvelmente conectados entre si, de maneira a que se um homem não se mexe no sentido de não ser livre, ou seja, se é servo, ele, ao mesmo tempo, não cometerá crimes. O homem só agirá de maneira maliciosa ou 
benéfica quando lhe for concedida liberdade para desempenhar tal ação. Portanto, em ordem de melhor combater atitudes imoderadas, a liberdade tende a ser suprimida. Tal é apontado na obra We de Yevgeny Zamyatin (2007).

Ao extinguir qualquer possibilidade de o homem fazer o mal, extingue-se, ao mesmo tempo, qualquer possibilidade de ele fazer o bem. Um homem servo da ordem é aquele que não exercita sua moral, mas ao mesmo tempo é aquele que não age em detrimento de outros homens (ZAMYATIN, 2007). Legislar significa tentar mudar a natureza humana, mas mais do que isso, transformar cada indivíduo de maneira a submetê-lo aos interesses coletivos (ROUSSEAU, 2014). "Em um mundo bom, entre homens bons, reina, naturalmente, apenas a paz, segurança e harmonia de todos para com todos; nesse cenário, fazem-se supérfluos tanto os padres e teólogos quanto os políticos e homens de Estado.” (SCHMITT, 2009, p. 70).

Incongruências atreladas à natureza humana tendem a levar instituições coercitivas a justificarem seus atos mais hediondos como sendo meros mecanismos de defesa, mas quem são os seus entusiastas e o que pensam da liberdade individual?

\section{Do pessimismo ao Estado autoritário}

Segundo Sardá y Salvany (1949) as liberdades morais e políticas são parte de uma infecciosa ideologia herética que corrói a alma dos povos: o liberalismo. Tais reivindicações representam o pecado demoníaco e inimigo da religião católica, isso porque predam na supremacia da fé ao afastar o homem de Deus e da hegemonia da Igreja. Trata-se de obra orquestrada por satanás para tentar os homens. Ao liberalizar os pensamentos, as ideias, as interações e as crenças estariam a rebaixar a religião católica a apenas mais uma religião; seria impulsionar uma peste infecciosa com asquerosas exalações de decomposição e gangrena: um pecado mortal.

A defesa da liberdade é tomada como ato mais vil do que ser blasfemo, ladrão, adúltero ou homicida. O homem para Sardá y Salvany (1949) não é um herói, o que abre margem para o seu posicionamento que confia na Igreja o papel de domar este selvagem naturalmente ímpio e violento. Como viver em 
6 | Opinião Filosófica, V. 10, n. 2, 2019 - Brasil Filosófico e seus pensadores

diversidade quando os homens são incapazes de coexistir em harmonia, mas atacam-se como selvagens em busca de sangue e impiedade?

Voltaire (2008: p.103) ampara essa justificativa ao dizer que "tal é a fraqueza do gênero humano e tal a sua perversidade que, indubitavelmente, é melhor que ele seja subjugado por todas as superstições possíveis, desde que não venham a causar assassinatos, do que viver sem religião." Com isso, se reivindica o interesse de uma força coercitiva, a da Igreja, para atuar como mecanismo apto a minorar conflitos. "O homem sempre teve necessidade de um freio e, ainda que possa ter sido ridículo fazer sacrifícios a faunos, ninfas e náiades, era bem mais razoável e útil adorar essas imagens fantasiosas da Divindade do que viver no ateísmo." (VOLTAIRE, 2008, p.103).

Burke (2016), por outro lado, reivindica a figura do Estado como capaz de restringir os vis intentos humanos. Ele aponta que o governo, assim como a liberdade possuem caráter benéfico, mas ao concedermos a liberdade, uma dádiva da humanidade, àqueles incapazes de com ela lidarem estaríamos a remover um louco da coerção protetora e da total obscuridade confortável de sua cela e colocando-o em uma liberdade lesiva, tanto a ele quanto aos sãos. Esse é o homem revolucionário francês de 1789: um animal selvagem; um louco liberto cujo instinto o dominará de maneira a tornar tanto a sua vida quanto as dos homens racionais um inferno na Terra. Com isso, Burke (2016) acredita que a Revolução Francesa é representada pela vitória dos doentes sobre a casta dominante; a vitória dos lunáticos sobre aqueles que detinham as chaves de seu hospício protetor.

Para Burke (2016, p. 30) a maior de todas as pragas que assolara a França era a liberdade individual, isso sob a justificativa de que a liberdade, para aqueles aptos de com ela interagirem, é uma bênção, enquanto que para os incapazes trata-se de uma maldição; trata-se de uma ferramenta para a escravidão deles mesmos. Aqueles em posição de irracionalidade serão servos de sua própria dependência e limitação. Não há nada mais hediondo do que uma anarquia de homens vis. Com isso, inquere ele acerca dos efeitos da liberdade dizendo que "o efeito da liberdade é de permitir aos indivíduos fazerem aquilo que lhes agrada: vejamos, pois, o que lhes será agradável fazer antes de nos arriscarmos a cumprimentos que muito cedo, talvez, devam ser convertidos em pêsames." 
"Constituir um governo não requer demasiada prudência. Estabeleça a sede do poder, ensine a obediência, e o trabalho estará pronto. Dar liberdade é ainda mais fácil. Não é necessário guiar; e requer apenas que se solte a rédea." (BURKE, 2016, p.252). Burke (2016) propõe que a liberdade outorga expectativas em necessidade de satisfação. Se os povos não se encontram em posição propícia para satisfazê-las não há que se falar em liberdade concedida aos povos, do contrário estariam a interagir com uma liberdade corrompida. "Os que sabem o que é a liberdade virtuosa não podem suportar vê-la desonrada por mentes incapazes em virtude das palavras altissonantes que lhes saem da boca." (BURKE, 2016, p.252).

Segundo Hobbes (2014) da natureza humana emana um sentimento narcisista e mau, a partir do qual se legitima um Estado presente em todas as esferas da vida individual e capaz de impedir a guerra de todos os homens contra todos os homens que resultaria da liberdade. Todo homem deseja poder, sendo o homem um lobo no tocante a outros homens. Quando esta premissa é fixada, a ideia de Burke (2016, p.97) de que "os reis serão tiranos pela política quando os súditos forem rebeldes por princípio" se torna mais compreensível. Nada mais sensato do que propor um modelo de Estado Absoluto quando da existência de tão vil natureza humana tal qual é a apontada por Hobbes (2014). Schopenhauer (2018) segue os mesmos preceitos:

O egoísmo, por natureza, não tem limites; o homem só tem um desejo absoluto, conservar a existência, eximir-se de qualquer dor, de qualquer privação; o que almeja é a maior soma possível de bem-estar, é a posse de todos os gozos de que é capaz de imaginar e que se esforça por variar e desenvolver incessantemente. Qualquer obstáculo que surja entre o seu egoísmo e as suas cobiças excita-lhe a raiva, a cólera, o ódio: é um inimigo que é preciso esmagar. Desejaria tanto quanto possível gozar tudo, possuir tudo; não o podendo, almejaria pelo menos dominar tudo. [...] $\mathrm{O}$ egoísmo é colossal, o universo não pode contê-lo. Porque se dessem a cada um a escolha entre o aniquilamento do universo e a sua própria perda, é ocioso dizer qual a resposta. Cada um considera-se o centro do mundo [...] Para pintar de um traço a enormidade do egoísmo numa hipérbole empolgante, cheguei a isto: Muita gente seria capaz de matar um homem para se apoderar da gordura do morto e untar com ela as botas. Só me resta um escrúpulo: será realmente uma hipérbole? (SCHOPENHAUER, 2018, p. 100-101).

Trata-se da lógica compartilhada por muitos pensadores conservadores a de que "o mundo é o inferno, e os homens dividem-se em almas atormentadas e em 
diabos atormentadores." (SCHOPENHAUER, 2018, p. 26). O mundo sendo um local de penitência aos culpados presos nessas imediações e atormentados por suas próprias incapacidades; sendo governados pelo acaso e pelo erro, dominados pela loucura e pela maldade, e asfixiados pela mentira contínua que é a existência é um mundo que necessita de instituições coercitivas para regulá-lo (SCHOPENHAUER, 2018).

Schopenhauer (2018) vai mais longe ao apontar que a vida do homem é um combate perpétuo, não apenas contra males abstratos, a miséria e o aborrecimento, mas também contra os outros homens, sendo que em toda a parte encontra-se um adversário e a vida é uma guerra sem tréguas na qual se morre encolhido com as armas na mão. O mundo como não sendo uma lanterna mágica que se admira as cores de suas montanhas, florestas, torrentes, animais e plantas, mas um ambiente repleto de atritos e sofrimento. Um campo de carnificina onde entidades ansiosas e atormentadas vivem devorando-se umas às outras e onde todo o animal carnívoro torna-se o túmulo vivo de tantos outros e passa a vida numa longa série de martírios; é onde a capacidade de sofrer aumenta na proporção da inteligência, e atinge, portanto, no homem o mais elevado grau.

Schopenhauer (2018) e Hitler (2018) condicionam a solução para os males terrenos como sendo única: o despotismo dos sábios e nobres, de uma aristocracia pura e verdadeira, corolário de uma geração composta da união de homens e mulheres selecionados para procriar a raça superior de governantes. Marquis de Sade (2008), em sua obra The 120 Days of Sodom exemplifica quem é esse homem mau que tende a legitimar modelos de Estado invasivos cujo pressuposto é tão reivindicado no pensamento político:

Ele estava fora da França, em uma província segura, nas profundezas de uma inabitável floresta, dentro da floresta em um esconderijo em que, tendo em conta as medidas que tomou, apenas aves poderiam aproximar, e ele estava na profundeza das entranhas da terra. Aflição, cem vezes aflição para a avarenta criatura que no meio de tal abandono se encontrar na misericórdia de vilões sem lei e sem religião, aos quais o crime excita, e obedecem senão aos decretos imperiais de sua suja própria ganância. (SADE, 2008, p. 45, tradução nossa).

Diferente de Sardá y Salvany (1949) que reverencia a Igreja, e de Hobbes (2014) que clama pelo Estado, ambos em face de um homem mau que motiva 
instituições coercitivas a segurar interesses, Ortega y Gasset (2016) critica a liberdade individual em função da existência de massas: um padrão de homem intelectualmente inferior e quantitativamente preponderante, mas de nenhuma forma malévolo em um sentido de tendencioso à violência.

Novamente a lógica empregada é a de que conceder liberdade a um homem que não sabe com ela interagir seria destruir a própria sociedade. Ortega y Gasset (2016) chama as massas de homens-massa, homens-médio e sábios-ignorante, propondo que um Estado desprovido de coerção institucionalizada em ampla esfera daria margem para que essa casta de indivíduos degradasse a vida e os valores de todos os outros e da própria sociedade.

Ortega y Gasset (2016) propõe que a obediência irá salvar as massas, enquanto que a liberdade as confunde em meio a um número excessivo de escolhas diferentes e complexas. Por serem incapazes de escolher com efetividade, elas sofrem. Assim, sem uma ordem, as massas têm uma vida de pura disponibilidade vazia. A existência de massas é a razão pela qual Ortega y Gasset (2016) defende a aristocracia cultural como sistema de governo, ou seja, o governo dos melhores homens culturalmente, o que impediria as massas de inferiorizar o meio político através de uma representatividade baixa e tendenciosa a obter representantes políticos também baixos.

Em outras palavras, o que Ortega y Gasset (2016) reivindica é que mandar sobre pessoas inaptas de decidir é dar às pessoas o que fazer; é metê-las em seu destino, impedindo sua inabilidade e extravagância; é impedir sua incapacidade contínua e inabdicável. Elas dão voltas num mesmo lugar sem saber o que fazer em um caminho que não leva a nada; vivem em um labirinto de escolhas as quais não conseguem elucidar ou mesmo reconhecer como existentes. A ordem impede as massas de desperdiçarem suas vidas e de viverem vidas vazias e sem objetivo. Assim, às massas resta obedecer, enquanto àqueles que não se enquadram em sua casta resta mandar.

Tudo isso gira em torno das expectativas que a liberdade outorga e da capacidade dos povos de satisfazê-las. Alguns pensadores mais conservadores, já citados ao longo do texto em inúmeras ocasiões, quando perguntados acerca de quem são os homens, responderão com pessimismo; quando perguntados sobre o que constitui a liberdade, um caráter de instabilidade e perigo lhe será atrelado; 
10 | Opinião Filosófica, V. 10, n. 2, 2019 - Brasil Filosófico e seus pensadores

quando perguntados dos requisitos para uma vida em liberdade, densas expectativas serão formuladas. Uma vida em liberdade outorga expectativas que, quando insatisfeitas em reflexo da condição dos povos, a premissa hobbesiana tende a ser levantada como justificativa à invasão do Estado nas esferas política, econômica e moral (FONTANA FILHO, 2019).

É a partir da ideia de homem mau que um modelo de Estado repressivo é estruturado. Amplo poderio é atrelado à figura dos detentores do poder político com o fim de estagnar o perigo que representa o homem. As leis atuam como impedimentos para o livre fluir da sociedade. Rotulam os homens de intolerantes e, com isso, instauram um Estado moral que impera valores aos seus cidadãos; taxam os homens de ignorantes e, com isso, um Estado antidemocrático é reivindicado; por fim, rotulam os homens de egoístas, tomando seus recursos de si e fazendo uso em seu nome em um Estado mercantilista ou intervencionista. A premissa hobbesiana funciona como um aparato que garante a legitimidade do poder do Estado ao remover poder individual e transmiti-lo aos governantes (NOCK, 2012).

"A receita do Estado é o próprio Estado" (BURKE, 2016, p.235), o que significa dizer que um Estado que tributa mais e que possui mais funções será um Estado mais poderoso. Eis o que Herbert Spencer (1982) afirma acerca do poder estatal em detrimento ao individual:

Toda interferência de Estado adicional fortalece a assunção tácita de que é dever do Estado lidar com os males e assegurar todos os benefícios. O aumento de poder de uma organização administrativa é acompanhado pela diminuição de poder do resto da sociedade de resistir a ainda mais crescimento e controle. (SPENCER, 1982, p. 54, tradução nossa).

"Em todos os governos do mundo, a pessoa pública consome e nada produz. De onde lhe vem, pois, a substância consumida? Do trabalho de seus membros." (ROUSSEAU, 2014, p. 97-98). Quando o poder estatal aumenta, o poder social diminui, sendo os estados Bolcheviques, Fascistas e Nazistas a total conversão de poder social em poder estatal (Nock, 2012). Assim como o Estado não tem dinheiro próprio, ele não tem poder próprio. "Todo o poder que tem é aquele concedido pela sociedade, mais o que ele confisca de tempos em tempos sob um pretexto ou outro; não há outra fonte de poder da qual o Estado pode retirar.” 
(NOCK, 2012: p.3-4, tradução nossa). Portanto, toda a reivindicação de poder feita pelo Estado deixa a sociedade com menos poder; não há e nem pode haver qualquer fortalecimento do poder do Estado sem uma correspondente e equivalente perda de poder social (NOCK, 2012).

\section{Do estado de natureza em Rousseau, Locke e Hobbes aos seus modelos de estado respectivos}

"Eu imagino os homens chegando ao ponto em que os obstáculos, prejudiciais à sua conservação no estado natural, sobrepujam, por sua resistência, as forças que podem ser empregadas por cada indivíduo para manter-se em tal estado." (ROUSSEAU, 2014, p.29). Assim sendo, esse estado primitivo de coisas não mais teria condições de subsistir, e o gênero humano pereceria se não mudasse sua maneira de ser. Não lhe resta outro meio, para se conservarem, senão formando uma soma de forças que possa sobrepujar a resistência, impelindo-os para a formação de Estados (ROUSSEAU, 2014).

Segundo Jean-Jacques Rousseau (2014) o Estado teve sua origem através de um contrato social formado pelos homens em face de sua inabilidade de lidar com os obstáculos prejudiciais a sua saúde e conservação. A vida em natureza primitiva não subsistiu, o que os motivou a, de modo a não perecer, criar instituições coercitivas capazes de subjugar o que lhes predava os interesses anteriormente.

"O que o homem perde pelo contrato social é a liberdade natural e um direito ilimitado a tudo que o tenta e pode alcançar; o que ganha é a liberdade civil e a propriedade de tudo o que possui." (ROUSSEAU, 2014, p.34-35). O homem ganha segurança e paz, mas perde a liberdade irrestrita que dispunha. $\mathrm{O}$ contrato social remove a autoridade que o homem possuiu dentro do estado de natureza, sendo esta outorgada a um ente imparcial. O problema fundamental cuja solução é dada pelo contrato social é representado pelas incongruências da vida em estado de natureza sob a ótica de Rousseau (2014), as quais darão lugar a um modelo de Estado orquestrado em ordem de endereçar a concepção de mal de seu autor. Como Rousseau (2015) enxerga bondade no homem natural, o seu modelo de Estado será erigido sob os moldes deste preceito, em meio à representatividade 
12 | Opinião Filosófica, V. 10, n. 2, 2019 - Brasil Filosófico e seus pensadores

intrinsecamente atrelada ao que ele considera ser o Estado. "Qual é o objetivo da associação política? É a conservação e a prosperidade de seus membros.” (ROUSSEAU, 2014, p.104).

"O tratado social tem por objetivo a conservação dos contratantes" (ROUSSEAU, 2014, p.50), o que significa dizer que tudo aquilo que for tomado como motivo de deterioração dos povos será utilizado como mecanismo propulsor do contrato social e das medidas necessárias para obstaculizar tais vícios iniciais. No estado de natureza o homem possui a liberdade natural, a qual é limitada pelas forças do indivíduo, assim como a posse de bens, um mero efeito da força, só sendo reconhecido como de outrem o que é tido como inútil. Dentro das fronteiras de Estado, por outro lado, o homem possui a liberdade civil e a propriedade de seus bens, ambas asseguradas pela autoridade do soberano (ROUSSEAU, 2014).

$\mathrm{Na}$ visão de Locke (2012), dentro do estado de natureza o fiscal, o juiz e o executor da lei era o próprio indivíduo. Na sociedade civil, cada indivíduo outorga à autoridade o poder de fiscalizar, julgar e punir, abdicando, assim, de seu poder individual de julgamento privado em prol de um novo árbitro: a comunidade. Assim, o que retirou o homem da vida em natureza foi a necessidade de uma autoridade imparcial capaz de prestar tutela sobre a sociedade, o que não poderia ser encontrado senão dentro da sociedade civil. Dos vícios da vida em estado de natureza surgem os Estados que, com poder coercitivo, podem combater as incongruências que lhe deram causa de ser.

O maior objetivo do contrato social, para Locke (2012), é a preservação da lei natural. O homem escolhe abdicar do estado de natureza e de sua liberdade absoluta em razão de seu gozo ser incerto e exposto à invasão de outros. Ele opta, portanto, pela submissão ante o poder da autoridade. A insegurança, os medos e perigos contínuos pesam mais do que a sua liberdade absoluta quando no estado de natureza. A lei natural não é suficiente para regular o egoísmo individual, daí da necessidade de uma autoridade que impere a norma através da força. A lei natural em estado de natureza é representada por condutas morais, o que significa dizer que o homem natural de Locke (2012) é limitado por sua consciência, mas não sendo suficiente, a representação de um Estado limitado pela lei natural se faz necessária. Em outras palavras, a visão do autor acerca de o homem ser naturalmente consciente é o que evoca o seu modelo de Estado mínimo e limitado. 
De acordo com Hobbes (2014) o estado de natureza representa medo recíproco. Trata-se de um estado de instabilidade que motiva o homem a, para dele sair, adentrar em sociedade civil e elencar um poder comum como soberano. A passagem do estado de natureza ao estado civil representa a passagem de um estado de instabilidade a um estado de ordem capaz de libertar o indivíduo do medo constante que o atormenta.

Quando não existe um poder comum capaz de manter os homens em respeito, temos a condição que se denomina guerra; uma guerra de todos os homens contra todos. Nesse tempo não pode haver lugar para a faculdade inventiva, pois seus resultados são incertos; consequentemente, não se pode cultivar a terra e nem navegar, não se utilizam mercadorias importadas que chegam por via marítima; não existem construções cômodas, nem máquinas para remover grandes pesos; não se desenvolverá conhecimento sobre a face da terra; nem cômputo do tempo, nem artes; não há cartas e nem sociedade; e o que é pior: existirá grande temor e perigo de morte violenta. "A vida do homem é, então, solitária, pobre, embrutecida e curta.” (HOBBES, 2014, p.96).

Hobbes (2014) reivindica que a origem do Estado ocorreu no momento em que o homem se mostrou apto a abdicar de seu direito a todas as coisas, optando pela paz e segurança ao aceitar um poder coercitivo e absoluto como soberano, criando, assim, um contrato social. Com o Estado, o indivíduo clama por submissão à autoridade em troca da proteção contra o perigo de morte iminente e medo constante orquestrado por homens naturalmente vis e sedentos por poder dentro do estado de natureza. No estado de natureza todos os homens têm direito a todas as coisas, nem o mais sábio ou o mais forte viveriam em paz em razão de outros poderem formar grupos e derrubá-los. Por terem direito a todas as coisas, os homens vivem em guerra constante com seus semelhantes por acreditarem estar o seu direito sempre a ser violado, afinal, têm direito a todas as coisas, o que inclui os corpos de outros e seus pertences.

Diferente dos modelos de Estado representativo de Rousseau (2014) ou do Estado mínimo e limitado de Locke (2012), em Hobbes (2014) o que consta como pilar inabdicável de sua teoria de Estado é uma premissa pessimista quanto ao conceito de homem. A partir desta, o seu modelo de Estado absoluto é construído tendo por fim endereçar o mal da liberdade humana. 
14 | Opinião Filosófica, V. 10, n. 2, 2019 - Brasil Filosófico e seus pensadores

O que determinou a multiplicidade de funções e poderes atrelados ao Estado foi a intensidade e a urgência das necessidades daqueles que se encontravam em estado de natureza. Assim, o quanto mais urgente e necessária forem as necessidades do homem, maiores serão os sacrifícios que ele estará disposto a aceitar em ordem de tê-las satisfeitas. Até mesmo o sacrifício da liberdade pode ser tomado como aceitável em face de homens famintos, nus, sem teto e inseguros. Quando se instila o medo no coração das pessoas, elas naturalmente optam por renunciar ao seu desejo de liberdade em ordem de se proteger dos possíveis males (MOLINARI, 2009). Isso acontece porque "os homens fizeram os reis para os homens e não para os reis; colocaram chefes à sua frente para que pudessem viver comodamente ao abrigo das violências e dos ultrajes [...]." (MORE, 2014, p.37).

Será o estado de natureza um estado de ameaça constante, muito hediondo como aponta Hobbes (2014), benéfico como propõe Rousseau (2015) ou apenas inconveniente como destaca Locke (2012)? O que há em comum é que, em todos os casos anunciados o Estado se mostra como fruto da necessidade humana. Dos vícios dentro do estado de natureza a proteção de instituições coercitivas se fez imperiosa (MOLINARI, 2009).

O que há de se perguntar é: o quão abrangente é essa necessidade de Estado? Se a necessidade deu vida ao Estado há que se falar no abstrato que representa o termo necessidade e, como já foi exposto, existem possibilidades que habitam este abstrato, sendo uma delas o pessimismo. Se encararmos com pessimismo a liberdade moral, política e econômica, iremos, como corolário inextrincável, atrelar ao Estado poderes e funções que atuarão de forma autoritária e em decréscimo ao poder social (SPENCER, 1982).

É o governo instituído para o propósito de regular a troca ditando para cada homem onde ele deve comprar e onde ele deve vender? As pessoas querem que lhes digam em qual religião elas devem acreditar, quais formas e cerimônias elas devem praticar, ou como muitas vezes elas devem atender a igreja aos Domingos? É a educação o objetivo contemplado? Eles pedem instrução na administração de suas caridades - serem ditos para onde eles devem doar, e quanto, e em qual maneira eles devem fazer a doação? Elas requisitam que seus meios de comunicação - suas estradas e trilhos - sejam designados e construídos para elas? Elas criam um poder supremo para dirigir a conduta em assuntos 
domésticos - para que lhes digam em qual parte do ano elas devem comer seus bois, e quantas vezes devem ser servidas em cada refeição? (SPENCER, 1982, p.185-186, tradução nossa).

A premissa hobbesiana em esfera moral atua como uma pressuposição de que os povos são intolerantes, desrespeitosos e incapazes de interagir de forma moderada com pessoas de diferentes cores, gêneros, sexualidades, nacionalidades, religiões, concepções morais e filosóficas razoáveis e características físicas. Em esfera econômica ela interage com a ideia de que os homens são egoístas, sedentos por poder ou desinteressados pelo bem-estar coletivo como fim em si mesmo, desconhecendo de seu dever subjetivo para com outros seres humanos em situação financeira menos vantajosa. Em esfera política ela funciona sob a hipótese de que as pessoas são ignorantes ou negligentes politicamente, ineptas de eleger os seus representantes e menos ainda os representantes que governariam uma coletividade (SPENCER, 1982).

Em cada uma dessas áreas de atuação, a premissa hobbesiana garante um Estado presente. O Estado moral outorga valores e molda o indivíduo ao padrão desejado pelos detentores do poder político; o Estado intervencionista toma bens, alimenta a máquina pública e redistribui o restante, fazendo uso de pouco para satisfazer as extensas demandas legítimas da sociedade; o Estado antidemocrático dificulta a representatividade e garante poderes incontidos aos governantes, anulando a ideia de Estado limitado pelo Direito de um lado e, de outro, fomentando a de Direito limitado pelo Estado (SPENCER, 1982).

\section{Conclusão}

A instintiva necessidade humana por proteção dá vida à premissa hobbesiana e aos modelos de Estado repressivos. Dentro do jogo de poder dos governantes, essa necessidade se mostra explorada pela ingenuidade e dependência coercitiva dos povos. Antes optam por terem suas liberdades privadas de si do que sucumbirem ao abstrato em potencial da agressão. Ateus, judeus, soviéticos, vietnamitas, iraquianos, mexicanos, árabes e todos aqueles tomados como suspeitos pelos governos representam o fator determinante para a garantia do poder de ação repressiva: o pessimismo. Políticas fundadas no pessimismo têm 
16 | Opinião Filosófica, V. 10, n. 2, 2019 - Brasil Filosófico e seus pensadores

a tendência natural de negligenciar os interesses dos indivíduos ao eleger fins coletivos como imperiosos de perseguição. Ao final do dia, os indivíduos é que serão perseguidos.

O caráter abusivo das políticas do medo já é uma marca contemporânea sob os novos moldes tecnológicos que potencializam a invasão do Estado na vida das pessoas. George Orwell (1992) previu isso com eloquência em sua obra, Nineteen Eighty-Four. As câmeras de segurança como força de vigilância constante não são apenas parte da sociedade, mas parte dos indivíduos em atuação como mecanismo de defesa dos seus interesses. O sentimento de autopreservação é enraizado no homem, o que garante a efetividade das medidas, mas isso não significa que o apelo seja irresistível. Quando a outorga moral, econômica e política se mostra presente, não é rara a oposição. Pressupõem-nos vis, mas o único modo de proválos equivocados se encontra na esfera de liberdade, maturação e satisfação das expectativas que ela exige. Até lá seremos servos dos Estados impositivos e de suas prerrogativas violentas.

\section{Referências}

BOBBIO, Norberto. O futuro da democracia: uma defesa das regras do jogo. 13.ed. São Paulo: Paz \& Terra, 2015.

BURKE, Edmund. Reflexões sobre a Revolução na França. São Paulo: Edipro, 2016.

CASTELLS, Manuel. Ruptura: a crise da democracia liberal. Rio de Janeiro: Zahar, 2017.

FONTANA FILHO, Maurício. O Estado arbitrário: entre grilhões e ameaças. Riga: Novas Edições Acadêmicas, 2019.

FONTANA FILHO, Mauricio; PERSICH, Queli Cristina Braz; TONEL, Rodrigo. (2019). Uma análise crítica dos debates presidenciais Norte-Americanos de 2012 $e$ 2016: a influência da linguagem como mecanismo corruptor dos povos. Temática, 15(5), 177 - 192.

HITLER, Adolf. Mein Kampf. United States: White Wolf, 2018.

HOBBES, Thomas. Leviatã ou a matéria, forma e poder de um estado eclesiástico e civil. 3.ed. São Paulo: Ícone, 2014. 
JACOBSON, Zachary Jonathan. Many are worried about the return of the "Big Lie". They're worried about the wrong thing, 2018. Disponível em:<https://www.washingtonpost.com/news/made-by-

history/wp/2018/05/21/many-are-worried-about-the-return-of-the-big-lietheyre-worried-about-the-wrong-

thing/?noredirect=on\&utm_term=.fa3bbe46570e>. Acesso em: 2 maio, 2019.

LOCKE, John. Dois tratados do Governo Civil. Lisboa: Edições 70, 2012.

MILGRAM, Stanley. Obediência à autoridade: uma visão experimental. Rio de Janeiro: Francisco Alves, 1983.

MISCHEL, Walter. O teste do marshmallow: Por que a força de vontade é a chave do sucesso. Rio de Janeiro: Objetiva, 2016.

MOLINARI, Gustave de. The production of security. Alabama: Ludwig Von Mises Institute, 2009.

MORE, Thomas. A utopia. São Paulo: Edipro, 2014.

NOCK, Albert Jay. Our enemy, the state. 3.ed. Caldwell: The Caxton Printers, 2012.

ORTEGA Y GASSET, José. A rebelião das massas. 5.ed. Campinas: Vide editorial, 2016.

ORWELL, George. Nineteen Eighty-Four. London: Everyman’s library, 1992.

PAUL, Ron. Definindo a liberdade: 50 questões fundamentais que afetam a nossa liberdade. São Paulo: Instituto Ludwig Von Mises Brasil, 2013.

ROUSSEAU, Jean-Jacques. Discurso sobre a origem e os fundamentos da desigualdade entre os homens. São Paulo: Edipro, 2015.

ROUSSEAU, Jean-Jacques. Do contrato social. São Paulo: Hunterbooks, 2014.

SADE, Marquis de. The 120 days of Sodom. Radford VA: Wilder Publications, 2008.

SARDÁ Y SALVANY, Félix. O liberalismo é pecado. São Paulo: Companhia Editora Panorama, 1949.

SCHMITT, Carl. O conceito do político / Teoria do partisan. Belo Horizonte: Del Rey, 2009.

SCHOPENHAUER, Arthur. As dores do mundo: o amor - a morte - a arte - a moral - a religião - a política - o homem e a sociedade. São Paulo: Edipro, 2018. 
18 | Opinião Filosófica, V. 10, n. 2, 2019 - Brasil Filosófico e seus pensadores

SCRUTON, Roger. As vantagens do pessimismo: e o perigo da falsa esperança. São Paulo: É Realizações, 2015.

SPENCER, Herbert. The man versus the state: with six essays on government, society, and freedom. Indianapolis: Liberty Fund, 1982.

VOLTAIRE. Tratado sobre a tolerância: por ocasião da morte de Jean Calas. Porto Alegre: L\&PM Pocket, 2008.

ZAMYATIN, Yevgeny. We. London: Vintage, 2007.

ZIMBARDO, Philip. O efeito Lúcifer: como pessoas boas se tornam más. 3.ed. Rio de Janeiro: Record, 2015.

Recebido em: 11/10/2019.

Aprovado em: 25/11/2019. 